\title{
Ongoing Diaspora: The Case of the French
}

\section{Caribbean}

Diaspora évolutive : l'exemple de la Caraïbe française

Diáspora en curso: El ejemplo del Caribe francés

\section{Mickaella Perina}

\section{OpenEdition}

\section{Journals}

Electronic version

URL: https://journals.openedition.org/remi/2708

DOI: 10.4000/remi.2708

ISSN: $1777-5418$

\section{Publisher}

Université de Poitiers

\section{Printed version}

Date of publication: 1 March 2006

Number of pages: $35-57$

ISBN: 2-911627-41-5

ISSN: 0765-0752

\section{Electronic reference}

Mickaella Perina, "Ongoing Diaspora: The Case of the French Caribbean", Revue européenne des

migrations internationales [Online], vol. 22 - $\mathrm{n}^{\circ} 1$ | 2006, Online since 01 April 2009, connection on 14

April 2022. URL: http://journals.openedition.org/remi/2708 ; DOI: https://doi.org/10.4000/remi.2708

This text was automatically generated on 14 April 2022

(c) Université de Poitiers 


\title{
Ongoing Diaspora: The Case of the French Caribbean
}

\author{
Diaspora évolutive : l'exemple de la Caraibe française \\ Diáspora en curso: El ejemplo del Caribe francés
}

\author{
Mickaella Perina
}

1 Trying to apply a concept to several realities and seeing if and how it is applicable is always a perilous enterprise, even more so when there is an initial divergence in the use of the concept. Traditionally, Anglo-American scholars tend to be more inclined to use the concept "Diaspora" than French scholars, who use it with parsimony -to say the least- when it comes to current transnational migrations and moreover to the people of African descent of the Caribbean. It is an important theoretical contention that certainly deserves scrutiny.

In 2002, Christine Chivallon expressed the difference between the two academic worlds by emphasizing the impact of another concept, namely postmodernism. In her view:

A comparative approach to the way in which the notion "diaspora" is used in

Anglophone and Francophone milieux confirms the presence of a similar succession of paradigms. Where postmodernism has flourished -in the Anglophone spherethe Black world of the Americas has found itself veritably consecrated as diasporic and endowed with new qualities. In the Francophone sphere, which is still open to a more conventional sociology, the use of the term functions minimally or not at all for the same Black American world, since that world is presumed to follow the contours of a classical diaspora, especially in the development of a powerful community consciousness. ${ }^{1}$

It is not my intent to question whether or not this contention is effectively based on the influence of postmodernism but rather to acknowledge it without considering it an obstacle to the examination of the "Black world" in the French Caribbean.

It is my view that the French overseas department constitutes an unusual case of modern diaspora and that it might have been a case of non-classic diaspora avant la lettre i.e. before post-modernism. Such a reading presents a number of difficulties that are not absent in other contexts but might appear important in this case. To that 
respect this case certainly adds to the variety usually acknowledged to diasporas and might as well be regarded as an unexpected or an unconceivable form of modern diasporas. But shouldn't the concept be open enough to incorporate such cases? Is the French overseas department the exception (in the Caribbean) that confirms the rule? Or is it an example that invites to reconsider and rethink permanently the concept itself?

5 An analysis of these departments provides an opportunity to ask a number of questions that are in my view important to a better understanding of modern diasporas in general. What types of border crossing effectively qualify as diaspora if the diasporic experience is to be different from transnationalism? Is assimilation necessarily incompatible with diasporic citizenship? Beyond these two choices, couldn't other perspectives occur if new forms of negotiations of identity can always be invented?

The purpose of this essay is to examine if and how it is possible to speak of an African diaspora in the case of the French Caribbean and what characterizes this diasporic dynamic. Firstly, I will examine what in the French Caribbean experience can count in favor of such determination by comparison with "qualified diasporas". Secondly, I will consider this "diaspora" in the light of Cohen's categorization of Caribbean diaspora as cultural diaspora. Lastly, I will explore some of the practices of the French overseas citizens and see whether or not they could qualify as "diasporic citizenship" practices.

\section{Defining the french overseas: a diaspora?}

7 What does it mean to say that a group of individuals constitute a diaspora? What makes an individual a member of a diaspora? Characterizing is always an arduous task since one of the correlates of defining is excluding. Characterizing requires determining or explaining the conditions under which a word or an expression has internal and external significance. The question of what a word means and when it is meaningful to use it is important, not only to an understanding of language but also to an understanding of human experiences. I would argue that it is therefore crucial to an understanding of "diaspora" regarded both as a concept and a human experience. Although a long detour through the philosophy of language and especially to Frege's analysis might not be necessary here, it is helpful to keep in mind the distinction Frege introduced regarding the meaning of words while considering the concept of "diaspora," and its various definitions and uses. Frege argues that the meaning of a name has two components, he distinguishes between the sense of an expression and its reference, between the thought it expresses and the object it represents. As he put it, "It is natural now, to think of there being connected with a sign (name, combination of words, letter) besides that to which the sign refers, which may be called the reference of the sign, also what I should like to call the sense of the sign, wherein the mode of presentation is contained"2.

8 Considering diaspora, the first difficulty one encounters is the question of its constitution. How does a diaspora come to exist? Considering such a question brings to light a number of distinctions. First, becoming part of a diaspora can result from a voluntary process of migration or from a forced project of relocation. Second, a diapora can result from the removal of massive numbers of a given society and their transfer to a single other location or dispersal to several others or from the accumulation of individual relocations from an initial society to another. As for the first description, 
there are difficulties inherent to the notion of "voluntary migration." How voluntary is a migration? How voluntary is it to "decide" to migrate to escape from hunger or diseases or to run away from arbitrary/authoritarian regime? How "chosen" is a migration that results from survival as opposed to a desire to better one's life? Voluntary migration is not a clear cut since migration is often, if not always, determined by some external cause rather than decided free of any external determination. Furthermore the circumstances in which one has to leave or decides to leave affect both the way in which one would rely to the homeland and the way she sees himself in relation to the homeland and to the community she will thereafter enter. This consideration is crucial for our subject to the extent that "voluntary" relocations in Europe and elsewhere of overseas French can be analyzed as a "diaspora of a diaspora, ${ }^{3 "}$ a modern diaspora of a classic diaspora although far from the initial dispersal of Africans on colonial plantations.

\section{Modern versus classic diasporas}

9 It is worth repeating that "diaspora" was initially conceptualized in light of a reference to an "origin in the scattering and uprooting of communities, a history of traumatic and forced departure, a sense of a real or imagined relationship to a homeland mediated through the dynamics of collective memory and the politics of return." ${ }^{4}$ This definition certainly enlightens what is common to the three "classic" diasporas the Jewish, the Greek and the Armenian as opposed to more recent conceptualization applied to the African Diaspora and focusing on the experience of the slave trade and slavery. According to this second conceptualization, the African diaspora can be better understood through the prism of concepts such as the "Black Atlantic"5 or the "AfroCaribbean." ${ }^{\prime \prime}$ Although the Greek etymology of diaspora suggests the scattering of people ${ }^{7}$ it also denotes "the people settled far from their ancestral homelands" as well as "the place where these people live."

How do the overseas French fit into that framework? It seems fair to consider that the French Caribbean qualified at a point of history as part of the African diaspora according to the classic definition. Slaves were indisputably brought to the islands forcibly and constrained to settle far from their homeland. They undoubtedly remain individually and collectively attached to their homeland as manifested in various cultural practices (language, arts, etc) despite the actual "politics of no return". As for the more recent conceptualizations, a number of justifications can be found to look at the French Caribbean as part of the "Black Atlantic" and at overseas French as "AfroCaribbeans." The slave Trade and the experience of slavery are foundational and have been determining human experience in that part of the world. ${ }^{8}$ The idea of a common experience in the Caribbean, certainly the idea of a 'Black Atlantic' with the plurality of its forms manifests its complexity and makes the act of defining a challenge. To the point that it might seem necessary to "shift[ing] the defining element of diasporan studies from the group itself to a methodological and theoretical approach to the study of the phenomenon of diaspora in human history. In other words, rather than being viewed as an ethnicity, diaspora may be alternatively considered as a framework for the study of a specific process of community formations." I would argue that the study of specific groups and their histories and the examination of their correspondence with, or on the contrary, distance from the concept will inform this framework and contribute to a better understanding of the "processes of community formations." 
11 How are we to consider the actual overseas French? Should they be considered as "Afro-Caribbeans"? Should these islands be seen as part of the "Black Atlantic"? If the word diaspora can be used indistinctly to denote the people and the place where they live, does the fact that one is born in the Diaspora makes one necessarily diasporan? Or can one stop to be diasporan? Is it enough to leave the diaspora (the place) to stop being a diasporan? "Is any length of residency in the diaspora sufficient to make one diasporan? At what point does being in the diaspora make one of it?"10 And how much awareness or self-identification is required to be a diasporan?

12 A number of questions regarded as relevant or fundamental in the context of "classic" diasporas seems to become problematic when attached to the African diaspora in general and to the French Caribbeans of African descent in particular. But such difficulties can be beneficial to the larger debate in the sense that, taken seriously, they can enlighten the way we think about diasporas and expose the complexities of such human experience. Consider, for instance, one of the main criteria according to "classic" diaspora conceptualization: the reference to the homeland. ${ }^{11}$ This issue might have been at the center of the debate in the late 1950's and early 60's in the French Caribbean, but it is clearly no longer the case today. Should one then conclude that since the politics of return are not fundamental this community cannot be looked upon as a diaspora? Couldn't it be argued that in this case the return was always thought as metaphorical?

\section{Politics of return, politics of memory}

13 Césaire's Notebook of a Return to my Native Land ${ }^{12}$ speaks to the idea of both a lost homeland that can be associated with a form of exile and the possibility of a return, but the return is to be mentally achieved rather than physically accomplished. Thus, the negritude movement can be analyzed as claiming the necessity of a linkage with the homeland without making the return a requirement. This approach is fully compatible with the view that these societies and territories are members of the African diaspora. It would be interesting to examine how much of the condition envisioned by the negritude movement and described by Césaire in the late 50's actually coincide with contemporaneous social and individual experiences and claims in these regions.

In any case, Glissant offers a different reading of the Caribbean experience and suggests focusing on the geographical genuine membership rather than a dreamed homeland. As he sees it: "Our diverse histories in the Caribbean have produced today another revelation: that of their subterranean convergence. They, thereby, bring to light an unsuspected, because it is so too obvious, dimension of human behavior: tranversality. The implosion of Caribbean history (of the converging histories of our peoples) relieves us of the linear, hierarchical vision of a single History that would run its unique course"13. This transversality indicated what will become evident in Glissants's later work under the concept of "identity of Relation" which described a particular aptitude to build social relations. As he put it "If century end (and the end of this century) seems significant, it is because at the same time, as one might say, it kept its function of pendulum of temporal linearity, but already surprised in the multiplicity of times and histories that rise from the bottom of the world and that reunite lastly, it no longer nods with as much absolute." It is worth noticing that in my view Glissant's perspective is dissimilar from the position of the founders of the Creolity movement, who claim an 
identity without foundational myth -as opposed to Césaire's negritude- but assert the necessary recognition of Creolity and Creole language as foundational. This later perspective presents its own difficulties and I shall return to the particulars of them along with their implications on the idea of African Diaspora and moreover on considering the French Caribbean as part of the African Diaspora.

The issue of processes and open-processes versus fundamental and absolute nature is addressed by Patterson and Kelley who assert that "linkages that tie the diaspora together must be articulated and are not inevitable and that the diaspora is both process and condition." They also add that, "just as the diaspora is made, it can be unmade and thus we must explore the moment of its unmaking." ${ }^{14}$ This perspective needs to be explored further in the context of the French Caribbean Afro-diasporic experience in relation to the assimilation both 'structural' and 'cultural' ${ }^{15}$ and to the resistance to assimilation. We shall return to that question in the last section of this essay; though it is certainly not innocuous to speak of overseas French while discussing African diaspora in the Caribbean.

Interestingly, considering the Afro-diasporic experience in the French Caribbean, one also has to think about a second type of migration, the displacement of those who have been "willfully" leaving the islands to enter the mainland society, to live in the Hexagon. In the late 1960's many Martinicans and Guadeloupeans migrated to France seeking employment, most of them through the BUMIDOM, a national program set to bring laborers to the mainland. These migrations were undoubtedly diverse and so were the conditions of departure and arrival that ultimately determined relations to the "homeland" (the islands) and to the "hostland" (the Hexagon). Interestingly, "hostland" and "homeland" constituted the same administrative entity, the same state and moreover a single destination. Therefore the claim can be made that it is not justified to speak of a diaspora in that case and that the term community is more adequate. However, the situation is more complex than it might seem. Firstly one might want to take into consideration not only migrations from the islands to the mainland but also from any given overseas department to any other overseas department which would make the destinations plural. Secondly if those individuals were already diasporan -members of the African diaspora when living in the Caribbean- how their relocation would make them stop being diasporan? If a Creole identity was constructed in the Caribbean and if it has to be understood as both "process" and "condition," it seems reasonable to consider that the process will continue and possibly create new conditions. To that extent, this diaspora can be regarded as one form of modern diaporas, of new waves of immigration result or condition of internationalism and transnationalism but can also be regarded as the transformation of a "classical diaspora" into a modern. "A bi-cultural identity [that] is not only the result of transnationalism but the very identity, on which transnationalism first depends, then relies and ultimately (over the course of time and further investments) cements." ${ }^{16}$

\section{Diaspora and (bi-)cultural identity}

17 The notion of bi-cultural identity fits the experience of the people of African descent in the French Caribbean but might be too tied. I would argue that the concept of diasporic identity corresponds better, to the extent that it allows a plurality -not limited to twoof components. The citizens of Martinique and Guadeloupe can certainly define 
themselves as Caribbean and French with no contradiction. But beyond this apparent dualism it is not unreasonable to envision various ways to express both French-ness and Caribbean-ness and various ways to weight the part of French-ness and of Caribbean-ness and moreover an infinity of ways to express Caribbean-ness that is itself plural. Many of these islanders who live on the mainland regard the islands as their homeland although it might become less true of those born on the mainland. It is fairly possible that the second generation and a fortiori third generation, regard the islands as the place their parents came from rather than their homeland. However, they might, at the same time, remain attached to a culture -or part of a culture- that identifies and singularizes them. Here again every attempt to define -and therefore to exclude- remains difficult and seems hardly compatible with the idea of an identity that is open, mixed, changing, and non-exclusive.

In any case it will be interesting to see how much of this permanently redefined subjectivity affects negotiations with the state and how these citizens -originally overseas citizens then mainland citizens- continue (or stop) to be members of the diaspora. Can one remain part of a diaspora in the absence of some type of attachment or reference to a "homeland" or to a community of fate in the absence of a possibility of return, either because one cannot return or because one chooses not to return? Does the end of the membership constitute the ultimate moment when both cultural/ structural assimilation and integration are realized? Are both cultural and structural assimilation required to move out of the condition of diasporan or does that create another form of diasporic experience -one that does not imply the possibility of return but supposes loyalties to both territories and political entities when cultural assimilation does not mean acculturation? If that is the case, then once again the French Caribbean in particular and the Caribbean in general can serve as examples of what diasporas can be, both as processes and conditions.

\section{Cultural diaspora, diasporic identity, creolization and hybridity}

\section{Cultural diaspora, diasporic identity}

Initially the focus of migration scholars diaspora has become a domain of investigations for scholars of cultural studies, post-modernism and post-colonialism. In the preface of the first issue of the journal Diaspora, Khacha Tölölyan stated that "Diaspora must pursue (...) in all cultural productions and throughout history, the traces and struggles over and contradictions within ideas and practices of collective identity, of homeland and nations." ${ }^{17}$ Within the concert of diasporas, the Caribbean presents its own characteristics and constitutes a prolific domain of research which can significantly contributes to an enhanced understanding of this human experience. As Agustin LaoMontes remarked "an Afro-diasporic approach from a Caribbean perspective is also changing the geographies, languages and theoretical domain of post-colonial theory." 18 But what exactly is an Afro-Diasporic approach? How are we to understand the "ideas and practices of collective identity and of homeland and nations" in the context of the Afro-Caribbean?

Cohen suggests that Caribbean diaspora be regarded as "one of the paradigmatic cases of a cultural diaspora, namely that of migrants of African descent from the Caribbean. 
19" As stated earlier, the people of Martinique and Guadeloupe could be considered as a diaspora without emphasizing the cultural. They could be categorized as another part of the African diaspora, or to borrow from Cohen, the 'African victim diaspora' when located in the Caribbean. But do they stop being part of the initial diaspora to become a cultural diaspora when they migrate to France or any other country?

Their situation is unusual in the sense that Caribbean migration in France essentially made of people from the French overseas departments can be regarded as internal migration. In that sense, this migration would manifest something of a "junction between diaspora and homeland" ${ }^{20}$ and would be different from the experience of other French Afro-Caribbeans elsewhere. It is worth noticing that this would concern also other groups such as people of Indian ${ }^{21}$ or Chinese descent from these territories. This "diaspora" within the Hexagone could then qualify as "national minority" in Kymlicka's perspective, which defines national minorities as cultural groups rather than racial groups. Indeed these societies, each of them with its particularities, present mixed ethnic features but define themselves from their common culture in which language is a determining factor. ${ }^{22}$ But would these groups then stop being part of the diaspora once they become "national minority" recognized or not? Before examining how much of this diasporic identity Antilleans are able to express in the Hexagon or wherever they relocate, one must interrogate the diasporic identity developed by French Caribbeans within the geographical boundaries of the Caribbean.

It is worth observing that "the determining factor," for instance the Creole language, was not initially officially recognized by the state. Over time, changes had been occurring and Creole entered a limited sphere of the mainstream spectrum with, for instance, the creation of elective Creole language classes in schools and of a national test for Creole language teachers. It is therefore important to acknowledge the constant and necessarily unachieved struggles that regulate the construction of this diasporic identity.

In this context there is a tension between cultural identity and political identity within which strategies are invented, resistances and contestations of inequalities are created and a diasporic identity is developed. I would argue that the political and cultural dimensions are entangled. Moreover, it is my contention that it is dangerous to focus exclusively on the cultural to the detriment of the other aspects of the dynamics of this human experience. As Chivallon rightly pointed out, "If diaspora is to help tackling identity without any previous consideration on the context that presides to its formation, taking the risk to keep silent the fundamental implication of the formation of social relations, then there is not much to gain from such a notion, if not for it to serve as an arbitrary tool to designate peoples." ${ }^{23}$

\section{Identity, creolization and hybridity}

24 This tension between the cultural and the political is of extreme importance in the sense that it echoes one of the difficulties mentioned in the first section of this essay and related to the notions of Creolization and hybridity. Considering the distinctiveness of Caribbean diasporic identity Hall demonstrated that "The diaspora experience [as I intend it here] is defined not by essence or purity but by the recognition of a necessary heterogeneity and diversity; by a conception of identity which lives with and through, not despite, difference; by hybridity. Diaspora identities 
are those which are constantly producing and reproducing themselves anew, through transformation and difference." ${ }^{24}$ One might want to examine the validity of such categorization and there are indeed interesting questions attached to the used of hybridity to refer to a conception of identity that is mixed, dynamic, and permanently changing but the focus here will be on what this word denotes and its implications.

The notion of hybridity is close to the idea of Creoleness developed in the French Caribbean. Both notions describe the openness of Caribbean identity. In Praise of Creoleness defines Creole identity as follows: "Based on its constitutive mosaic, Creoleness is an open specificity. To express it (...) is to express a kaleidoscopic totality, which is to say the non-totalitarian conscious of a preserved diversity" (emphasis added). However the authors also state: "We declare that Creoleness is the cement of our culture and that it must govern the foundations of our Antillean-ness." ${ }^{25}$ Claiming openness, the authors assert authenticity through an exclusive foundational principle and therefore, in my view, set limits and determine criteria of exclusion. They agree on a frontier between what is authentically Creole and what is not and a fortiori between what is legitimate and what is not. To that extent Creoleness can be interpreted as paradoxically "consecrating another frontier between self and other," ${ }^{26}$ between what is effectively Creole as opposed to what is not. These positions express the complexity of writing and examining construction of identity in general and diaspora in particular. However, if we are to take seriously the idea of a plural, diverse, non-totalitarian, "kaleidoscopic", non-absolute identity, we must allow room for all possible forms of this experience, including the unexpected or the disturbing.

Taking these objections into consideration, we are left with what seems to be an inherent difficulty of Creoleness explicitly or implicitly defined as an authentic condition, and we must return to Creolization as a process and try to find ways to approach these identities. But the position required here is one of uncertainty, imbalance, possibility and movement and it is a difficult standpoint. One possible satisfactory answer might be found in Glissant's suggestion of a "Poetic of Chaos." In his perspective, chaos is not to be understood as a state of confusion but rather as an inherent unpredictability, a process compatible with a condition and yet non exclusive. As Glissant puts it:

I'll start from a poetic of the actual positions of the being-in-the-world and the evident vision will be that the being is chaotic. The question that arises is the following: this chaos that fissures the being and divides the world is it the chaos that precedes apocalypses, ends of world, as a certain literature defines it? [...] My Poetic is totally the opposite. My poetic is that nothing is nicer that the chaos- and that there is nothing nicer than the world-chaos. ${ }^{27}$ "

As convincing and seducing as the "Poetic of Chaos"s might be, it does not seem to address the social and political aspect of the diasporic identity. I would certainly subscribe to the idea of a cultural diasporic identity but I want to suggest that this cultural diaspora needs also to be regarded as partly political to the extent that the cultural is nourished of political and social struggles.

\section{Overseas citizenship: diasporic citizenship?} of cultural diaspora Cohen envisions two alternatives: 
At a deeper level, French Antilleans have always shared a Faustian pact with the French state. Should they choose to abandon their Africanness and embrace Mother France, they would become French people, citizens, members of a world culture and civilization. Two possible consequences arise from this pact. The more positive is that the French live up to the revolutionary ideals of liberty, equality and fraternity.(...) The more negative outcome, of course, would be if the path of assimilation were to turn out to be an illusion, a trap, ultimately a hoax. This would be the cruelest consequence of all -for the French Antilleans in continental France would become a liminal people, no longer able to express their distinctive ethnic identity or recover a sense of "home." 28 complete success and Antilleans will become full French citizens and share French
culture or it is a failure and Antilleans in France would be lost unable to "express their ethnic identity." I'd like to suggest a third perspective that could take various forms. I believe Gordon's distinction between "structural" and "cultural" assimilation provides a framework that can help considering this third possibility, an outcome in which a structural and political assimilation is realized successfully and where cultural assimilation does not necessarily have acculturation as an immediate correlate. It seems to me that if this identity is to be considered as open we should accept that all individuals might not define themselves the same way. In the context of other diasporas, it is important to acknowledge that some members might choose not to return (when returning is a viable option). Similarly I suggest that if we are to think in non-authoritarian terms about the French Caribbean we should also be prepared to consider those who might choose to completely assimilate. However, since this assimilation would not be enforced upon them it would remain possible for those who want to maintain a distinctive cultural identity to do so either against the dominant culture or along with it.

Political and/or cultural assimilation is not necessarily incompatible with diasporic citizenship. In that perspective, I agree with Hintjens that decolonization is possible without formal state ${ }^{29}$ and argue that some form of Laguerre's concept of diasporic citizenship $^{30}$ is applicable in the very specific form of "internal migration" that characterizes the French Antilleans in the Hexagon as long as one can think of "homeland boundaries" that do not correspond with the borders of a nation-state.

It seems that the notion of "diasporic citizenship" can first and foremost be applied to the French overseas citizens who relocate in Europe or elsewhere in the world with the exception of France itself. According to Laguerre,

The concept of diasporic citizenship adds the transnational aspect to the classic definition of citizenship. We conceive of diasporic citizenship as the situation of the individual who lives outside the boundaries of the nation-state to which he or she had formally held primary allegiance and who experiences through transnational migration (or the redesign of the homeland boundaries) the subjective reality of belonging to two or more nation-states. Diasporic citizenship includes both national and transnational outlook, attachment, and commitment. ${ }^{31}$

This definition seems indeed compatible with French overseas citizens who relocate outside France and initially had primary allegiance to France and France alone. In other words, the practices of border crossing that count in this context are the ones that exist between nation-states. Indeed Laguerre states "By diasporic citizenship, I mean a set of practices that a person is engaged in, and a set of rights acquired or appropriated, that cross nation-state boundaries and that indicate membership in at least two nation- 
states." ${ }^{32}$ In that sense diasporic citizenship refers to practices of nation-states border crossing. It seems that such a scheme could be applicable to the French overseas citizens relocated anywhere except in France and who would not be fundamentally different from any other diasporic citizen of our time. But how are we to understand the French overseas citizen from any of the overseas departments who relocate in the Hexagon? Is the nation-state the only possible source of political membership and of allegiance? Is it unreasonable to think about hierarchy of allegiances or simply diversity of allegiance where there is no formal state precisely because here decolonization occurred without the construction of an independent state? Can't the overseas department be the regarded as the administrative and political entity that will justify along with the state multiple allegiances? Can't they be described as "diasporic citizens" simply because their relocation happens to be within the state? How is the "primary" allegiance determined? If citizenship is different from total assimilation in the sense that it authorizes negotiations of identities and if, as Laguerre puts it, "Diaspora is [thus] both a residence and a state of mind. It has a subjective content as well as an objective quality" then it is certainly worth examining how negotiations of identity have been occurring in the French overseas departments and whether or not overseas citizenship practices can be described as "diasporic citizenship."

\section{A non-exclusive peripheral citizenship}

French overseas territories certainly present a complex category that makes them particular French entities and creates citizens of a specific kind. The status of the overseas department has often been regarded as an enigma among contemporary nations and sometimes interpreted as neo-colonialism. Interestingly, this particularity is recognized by both sides, by overseas citizens who request the recognition of their cultural specificity, and more surprisingly, by the state and its institutions. The French Constitution stipulates (article 73) that "the $\mathrm{DOM}^{33}$ legislative regime and administrative organization can be subject to modifications required by their particular situation." How to reconcile article 2 that claims the indivisibility of the state and article 73 that allows room for adjustments due to their specific situation? How do we understand the idea of "particular situation?" Does it refer to a geographical, historical, economical or cultural situation? Can the French Republic be considered effectively one and indivisible if laws and rights are in some occasions different for some citizens?

Obviously, Article 73 authorizes special treatment for these citizens and therefore presents the risk of making them second class citizens as opposed to citizens par excellence since this article manifests the possibility of a tyranny of the majority. As Tocqueville puts it:

What is through a majority considered collectively if not an individual who has opinions and more often interests opposed to another individual called minority? So if you admit that a man dressed with his power can abuse its adversaries with it why don't you admit the same thing for the majority? By grouping themselves did men change their character? Did they become more patient in front of obstacles by becoming stronger?

French overseas departments appear as a place for potential differentiation through exceptions. In principle and according to the French constitutions of 1946 and 1958, the assimilation of these territories was effective. Nevertheless, the validity of article 73

Revue européenne des migrations internationales, vol. 22 - $n^{\circ} 1$ | 2006 
has been demonstrated in countless situations, sometimes at the expense of the territories, sometimes to their advantage. The institutional history of these territories shows how similarities or on the contrary specificities can be emphasized. This invariant in history suggests a practical incompatibility between the first idea of complete assimilation and the effective judicial organization of the DOM. It indicates an irreconcilable difference between utopia and reality. The history of the French overseas possessions has been marked by two aspirations that happen to be hardly conciliatory: a desire to prohibit distinction between citizens and differentiating adjustments required by historical conditions and social struggles.

The overseas citizen can be analyzed as having the position of a "peripheral citizen" not entirely out of the State and yet not completely within the State. Other and same, the overseas citizen constitutes to some extent, an anachronism in a state that essentially values sameness. Such a situation could be expected to be propitious to nationalism and consequently to secessionist requests; but secessionist movements have never been extremely strong in these territories. Why not? Why no strong secessionism? Clifford's account on diasporic cultures and nationalism are of special interest here. He asked: "But are diaspora cultures consistently antinationalist? What about their own national aspirations? Resistance to assimilation can take the form of reclaiming another nation that has been lost, elsewhere in space and time, but powerful as political formation here and now." ${ }^{34}$ Resistance can take various forms and does not need to be antinationalist. It can take the form of citizenship that is conceived as non-exclusive, that allow room for culture politics. Overseas French citizens express sameness and otherness within the French republic which can certainly be seen as only the result of a long process of structural integration and cultural assimilation but that can also be regarded as the result of choices and struggles to be both French citizens and members of a cultural diaspora in the Caribbean or members of the Caribbean diaspora anywhere else. Nationalism was more or less promoted at some moments in time, it was ruled out at others. In a permanent enterprise of adjustment and construction, the French Antilleans express a diasporic political cultural identity.

Political culture is transmitted through processes of political socialization that are related to national identifications. Struggles and resistance organized by individuals or by groups are intrinsically related to processes of internalizing a given political culture. This internalization is independent of the use a given political order might make of collective identities for its own end. "National identity describes that condition in which a mass of people have made the same identification with national symbols -have internalized the symbols of the nation- ${ }^{35}$ " The final result is the construction of a "national imaginary." It seems fair to say that most French Antilleans have internalized symbols of liberty and equality that are usually attached to the French Republic and have made them part of their national imaginary. I would argue that the Antilleans make these symbols theirs by struggling for equality and pushing institutions to rise to the highest standards attached to the principles. To that extent, political membership and relation with the territory are based on a complex relationship that includes imaginary and symbols, not just geography or history. The study of the complex history of these departments certainly speaks in favor of such an interpretation.

Since its origins in the eighteen-century, nationalism has been based on two particular models of the nation and national identities have taken the form of a combination of 
these two models: the territorial civic model and the ethnic model. The civic model is based mainly on a territorial conception of the nation as a source of loyalties. The territory is associated with a particular historical-memory and the nation is mainly a juridical-legal entity that presupposes the legal equality of its members along with a common civic culture. On the other hand, in the ethnic model of the nation, the emphasis is placed on the community of common descent. The "people" is defined not mainly as a political ensemble subjected to the same laws and institutions, but as an ethnic ensemble that shares a similar language, analogous customs and other cultural manifestations. These two different 'ideal types' are in practice combined in different proportions in concrete cases of national imaginary. The nation as an imagined political community always has components of both models although the models are based on two different symbolic constructions of a sense of community.

The identity of a community is defined by the characteristics of its borders that are not absolute. These borders are subjects to the effects of social interaction and even at the most stable moments contain mixed feelings and internal fissures. ${ }^{36}$ The construction of the borderlines of a community can be seen as mainly a symbolic/ritual process. Different resources are used to develop a symbolic discourse that evokes feelings of affinity and/or of alienation from which the community is built and the (re)construction of the past is a fundamental resource for this purpose. The various controversies around the commemorations of the abolition of slavery in 1998 illustrate the significance of the politics of memory within the symbolic construction of a sense of community and national imaginary.

On the islands commemorations were primarily designed to emphasize the importance of slaves' revolts in the process of emancipation while when it occurred on the mainland the emphasis was exclusively on the "Abolitionists" and especially Victor Schoelcher. At first, one might analyze this difference in prominence as the manifestation of two different imaginaries almost incompatible with each other. Interestingly, these differences were not considered as justified or satisfactory, and on both sides people struggled to make slaves' revolts part of the discourse on the mainland and the abolitionists' work part of the one on the islands. In other words there was an attempt to create a national narrative. The borders of the political and cultural identity are not static, or absolute they result from social interactions, negotiations, and various forms of resistance. In an attempt to make slavery and emancipation part of the national imaginary a national date (May 10) to commemorate the abolition of slavery was made official by the president Chirac recently. It is an attempt to make available a day for the nation as a community of memory to commemorate the emancipation of slaves on French soil. But how do individuals relate to symbolic discourse remains an important question as well as what make them accept or reject it. What is ultimately the relation between individuals and the community?

\section{On-going construction of political identity}

41 As Bruce Lincoln put it "The idea of cultural-political identity is a particular answer to the wider question of the relationship of individual and collectivity. ${ }^{{ }^{37}}$ The relationship of individual and collectivity and their modalities are multifaceted, especially when political-cultural identity is regarded as "a matter of the creative response of groups to the structural circumstances enfolding the collectivity, which they inhabit." ${ }_{38}$ It is my contention that the on-going construction of political identity in the French Caribbean 
was initially determined by the struggles by which former slaves proceeded to make their new French citizenship significant. It later depended upon the ways by which they could and could not fully express this citizenship and still depend upon a dialectic between what citizens expect from their membership and what the state and the rest of society recognize as legitimate.

In an attempt at specifying a moment in the development and the construction of the political identity in the French overseas department, I will now focus on the departmentalization (1946) regarded as foundational in the on-going construction of this political identity. The choice of this event is arbitrary but found its legitimacy in the fact that it constituted a surprising way out of colonialism as I see it and was described by its advocates as a step forward in the direction of equality although it has been interpreted as a form of neo-colonization.

The departmentalization -the transformation of an old colony into a French overseas department- was voted almost a century after the abolition of slavery (1848) in an attempt to achieve social equality and make the citizens of the colony join the "national community" validating a full political membership. To that extent the departmentalization of the old colonies constituted in the eye of its supporters the achievement of the Emancipation Act. In these colonies, the notion of freedom was strongly related to the idea of republic and citizenship was seen as a corollary of emancipation. The first abolition in 1789 (which did not affect Martinique) was decided by The French Republic and later overturned by the First Empire. Departmentalization was supported by republican principles. Propositions to transform the colonies into departments and especially conclusions written by the commission in charge of discussing them, mentioned explicitly the concern for social justice and equality and referred to both status citizens and slaves. Aimé Césaire presented the conclusions as follows:

Since we can judge these experiences stepping backwards, we can affirm without risk of error that the tendency of all authoritarian regimes was to reject Martinique and Guadeloupe out of the national community. And that on the contrary the tendency of all liberal regimes was to separate these territories from decrees and admit them in the benefit of French law generosity. [...] The reason is that almost no effort has been made to ensure the Antilles and Reunion Island workers a social and economical status in agreement with the political status they have for one century. [...] To resume, we do not hesitate to affirm that almost a million of French citizens, Antilles, French Guiana and Reunion Island natives, are given up to the avidity of uncontrolled capitalism. Then one finds himself repeating Diderot's words: "To have slaves is nothing. What is intolerable is to have slaves and called them citizens". 39

This is an example of the relation with the state that expresses the construction/ reconstruction of the past and its participation within the national imaginary, the liberal regime being associated with equality before the law. I see this relationship with the state as revealing a conception of citizenship and nationality strongly connected with the perception of the national territory. As Gaston Monnerville, also a member of the commission puts it, "After fraternity and freedom, we come now to ask you for equality before the law, for equal rights." Clearly the crossing over from slavery to citizenship ${ }^{40}$ was a strong symbol that played in favor of the French Republic and republican ideas over a very long period of time and the departmentalization was a request for the fulfillment of the third principle symbolizing the republic. Moreover, it was a request for full membership in a community of equal citizens, a request for 
effective structural assimilation that does not necessarily include cultural assimilation. To that extent, the departmentalization expressed the inheritance of the emancipation and constituted an attempt to correct what had failed. It acknowledged the inheritance of slavery to the extent that it is regarded as a way to escape from the colonial order along with its judicial and legislative regulation in which discriminations against people of African descents were determined by an ideology of classification of mankind.

Not surprisingly, planters regarded the abolition act and its corollary (French citizenship) as non-legitimate. They denied slaves any participation in their emancipation and therefore considered the Abolition Act both as an undeserved gift and an arbitrary political decision. In that sense, after the Emancipation the békés (settlers in Martinique) used the idea of "being French by decree" as an insult to former slaves. "As for you, you are French only by decree. By enjoying as you are a decree expressed by surprise from 1848 provisory government, you are denying Africa to which you owe your origin, you are just African renegades." ${ }^{41}$ These considerations were based on a distinction between jus solis and jus sanguinis. According to the colonial ideology, blood was the only legitimate criterion to determine the membership within the community of French citizens. Citizenship has an inclusive virtue but it also has an exclusive dimension that in final analysis helps maintain the value of the membership. Thus, the integration of former slaves -necessarily excluded in respect to blood criterion- did not appear legitimate to planters and "residency" (jus dominici) was not enough when African origins were "obvious." In the late years of the old colonies, the struggle was between membership based on a relation with one's origins and membership based on a relation with a territory both conceived as exclusive. The vote of the departmentalization can certainly be regarded as the choosing of the territory over the origins but such political choice does not necessarily entail acculturation or loss of distinctive cultural identity even if the bourgeoisie of color was attached to French culture.

Indeed the elite and bourgeoisie of color chose to pursue what they considered an unachieved process for various reasons including the prominence of French culture among their group. As Armand Nicolas stated about Martinique, it was the small and middle bourgeoisie of color that ensured the political and ideological direction. This social group, strongly impregnated with French culture, was for a long time, bearer of the ideas that intended to claim civic and political equality between whites and people of color. Its main allegation was access to French citizenship, the assimilation to what was already called mother country. ${ }^{42}$ I would agree with Nicholas but I would immediately acknowledge that if one of the cause was a shared French culture acculturation was not necessary a collective project and moreover if it was a project it was not successful. It would be difficult to deny the impregnation of French culture in the French oversees departments but it would be as difficult to consider the Antilles today and pretend not to notice a distinctive Creole -mixed and diverse- culture extremely alive. To say that is not to pretend that every individual identifies with all components of that mix at all times, but that everyone identify with some parts of the mix -and not necessarily the same parts- at some time. The republican ideals were considered fundamental in the sense that they were associated with freedom and made French citizenship possible for former slaves. The fact that the state ultimately failed to effectively integrate the new citizens was considered a regression due to the 
authoritarian regime (the $2^{\text {nd }}$ empire) that followed the second republic, not to the republic itself.

47 I analyze this political moment as one of several manifestations of French overseas political and cultural identity in the sense that it shows both legacy of slavery, emancipation and colonization along with the influence as well as the appropriation of French republican principles. It is hard to consider the political without culture politics and the cultural without politics of memory and identity politics. The effects of this particular choice were reconsidered and readjusted in the early eighties with the regionalization and the attribution of extended local decision-making. However this choice still affects the relation between the citizens and "their" territory (physical or symbolic) and how these so-called "internal migrants," are regarded in France and how the Afro-Caribbean are considered in the Caribbean, in France or anywhere else.

\section{Conclusion}

Contemporary France is increasingly diverse and contains several historical communities with different cultures spread over its discontinuous territory. Within that framework, overseas French citizens can be considered as a crucial example of diasporic political, cultural experience due to the various implications of a past of slavery and to their allegiance to territories located outside the state which administrative status varied over time (colony, department, department and region) combine with their allegiance with the French state and to their linkage to a distinctive cultural identity. Diaspora is also a state of mind and to that respect concern overseas citizens who relocate in France or in Europe and therefore do not cross any national boundary as much as any other "foreign national" who does cross a national boundary. Taken seriously the historical experience of French overseas citizens and the on-going process of the construction of their political identity could contribute to a better understanding of the articulation of citizenship and territory and of citizenship and culture.

Immigration in France has often been regarded as a controversial political issue rather than a legal question. Likely the question of "minority rights" is often considered in regard to immigration law which induce confusion that are manifest in the use of terms such as: "immigrants," "foreigners," "young that have issued from immigration," "second generation of immigrants," etc. The politics of homogenization constitute a tradition in France but as the structural integration yet not cultural assimilation of overseas French citizens demonstrate processes of cultural and linguistic homogenization have limits and never totally exclude the upholding of particularities. To deny them is dangerous for the society as a whole. As Balibar pointed out “...there exists a double tendency to elevate a given definition (e.g. the equation of citizenship and nationality) or conversely to consider citizenship a mere "legal fiction" which expresses nothing but the mask of domination." ${ }^{43}$ Considering diasporic citizenship could provide a third and productive approach.

It is my view that overseas French citizens of African descent who identify themselves with the experience I described in this article qualify as members of the African diaspora combine with a French citizenship without contradiction. It is not my contention that they are de facto Afro-Caribbean by virtue of being born on this territory or by virtue of being of African descent. As stated earlier it does not seem 
unreasonable to me to think that some might choose to assimilate completely and to claim other identities. However those of them who relocate qualify as Caribbean diaspora whether they consider France or any overseas territory or both as their primary or secondary "homeland." But as I argued in this essay, their political cultural identity is built upon negotiations with the state based on politics of identity and politics of memory. To that extent, "diaspora" convey a meaning that "community" does not, namely the sense of border crossing and of a special link with a homeland, symbolic or physical.

\section{BIBLIOGRAPHY}

AFRICAN STUDIES REVIEW, vol. 43, 1 (April 2000), special issue on Diaspora, "Unfinished Migrations: Commentary and Response," Brent Hayes Edwards, Cheryl Johnson-Odim, Agustin Laó-Montes, Michael O. West, Tiffany Ruby Patterson, Robin D.G. Kelley (Éds).

BALIBAR Etienne (1988) "Propositions on Citizenship," in Ethics, vol. 98 (4), pp. 723-730.

BERNABE Jean, CHAMOISEAU Patrick, CONFIANT Raphaël (1989) Eloge de La Créolité, Paris, Gallimard, $69 \mathrm{p}$.

BERNARD Philippe (2002) Immigration le défi mondial, Paris, Gallimard, 346 p.

BLOOM William (1993) Personal Identity, National Identity and International Relations, Cambridge University Press, 206 p.

BRAZIEL Jane Evans, MANNUR Anita (2003) Theorizing Diaspora: A Reader, Blackwell Publishing, 345 p.

BUTLER Kim (2001) Defining Diaspora, Refining a Discourse, Diaspora, 10(2), pp. 193-194.

CÉSAIRE Aimé (2001) Notebook of a Return to my Native Land, translated by Clayton Eshleman and Annette Smith, Wesleyan University Press, 66 p.

CHIVALLON Christine (2004), La Diaspora Noire des Amériques, Expérience et théories à partir de la Caraibe, Paris, CNRS édition, collection Espaces et Milieux, 258 p.

CHIVALLON Christine (2002) Beyond Gilroy's Black Atlantic: The Experience of the African Diaspora, Diaspora, 11(3), pp. 359-382.

CHIVALLON Christine (1997) De quelques préconstruits de la notion de diaspora à partir de l'exemple antillais, Revue Européenne des Migrations Internationales, 13, pp.149-160.

CLIFFORD James (1994) Diaspora, Cultural Anthropology, 9(3), pp. 302-338.

COHEN Robin (2001) The Diaspora of a Diaspora: The Caribbean Case, in Harry Goulbourne Éd., Race and Ethnicity: Critical Concepts in Sociology, vol. 2 Solidarities and Communities, London: Routledge [Reprinted from Social Science Information, 31 (1), 1992, 193-203.

COHEN Robin (1997), Global Diaspora: An Introduction, London: UCL Press and Seattle: University of Washington Press, 224 p. 
COSTA-LASCOUX J. (1989) De l'immigré au citoyen, Paris, La Documentation française, notes et études documentaires, 1989, $160 \mathrm{p}$.

FREGE Gottlob (1980) “On Sense and Reference," in P. Geach and M. Black Éds., Translations from the Philosophical Writings of Gottlob Frege, Oxford, Blackwell, 228 p.

GILROY Paul (1993) The Black Atlantic, Modernity and Double Consciousness, Harvard University Press, $277 \mathrm{p}$.

GIRAUD Michel (1997) La Créolité: Une rupture en trompe-l'oeil, Cahiers d'Etudes Africaines, 37, pp. 795-812.

GLISSANT Edouard (1994), Le chaos-monde, l'oral et l'écrit, in Ralph Ludwig Éd., Ecrire la «parole de nuit ", la nouvelle littérature antillaise, Paris, Gallimard, Folio Essais, pp. 111-129

GLISSANT Edouard (1990) Poétique de la Relation, Paris, Gallimard, 248 p.

GLISSANT Edouard (1989) Caribbean Discourse, translated and with an introduction by Michael Dash, University Press of Virginia, $324 \mathrm{p}$.

GORDON Milton (1964) Assimilation in American Life, The Role of race, Religion and National Origins, New-York: Oxford University Press, 286 p.

HALL Stuart (1994) Cultural Identity and Diaspora in Laura Chrisman, Patrick Williams Éds., Colonial Discourse and Post-Colonial Theory: A Reader, Columbia University Press, New York, pp. 392-403.

KYMLICKA Will (1995) Multicultural Citizenship: A Liberal Theory of Minority Rights, Oxford Clarendon Press, New-York, 296 p.

LAGUERRE Michel (1998) Diasporic Citizenship: Haitian Americans in Transnational America, New York: St. Martin's Press, 232 p.

LECA Jean (1983) Question sur la Citoyenneté, Projet, pp. 113-125, 171-172.

LINCOLN Bruce (1989) Discourse and the Construction of Society: Comparative Studies of Myth, Ritual and Classification, Oxford University Press, p 238.

NICOLAS Armand (1967) La Révolution antiesclavagiste de Mai 1848 à la Martinique, Fort-de-France, Martinique, $32 \mathrm{p}$.

NACER Kettane (1986) Droit de réponse à la démocratie française, Paris, La Découverte, $141 \mathrm{p}$.

PEDRAZA Silvia (1999) Assimilation or Diasporic Citizenship in Contemporary Sociology, 28 (4), pp 377-381.

PERINA Mickaella (1997) Citoyenneté et sujétion aux Antilles Francophones, post-esclavage et aspiration démocratique, Paris, L'harmattan, 207 p.

PERINA Mickaella (2001) Crossing Over from Slavery to Citizenship: Origins of Modern French Caribbean Democracy in Serge Mam Lam Fouck Éd., Regards sur l'Histoire de la Caraibe, des Guyanes aux Grandes Antilles, Paris, Ibis Rouge, pp. 229-241.

PRESTON, Peter (1997) Political/Cultural Identity, Citizens and Nations in a Global Era, SAGE Publications, London, $208 \mathrm{p}$.

SAFRAN William (1991) Diasporas in Modern Societies: Myths of Homeland Return, Diaspora, 1, pp. 83-99.

SCHNAPPER Dominique (1991) La France de l'intégration, Sociologie de la Nation en 1990, Paris, Gallimard, 307 p. 
SCOTT David (1997) An Obscure Miracle of Connection: Discursive Tradition and Black Diaspora Criticism, Small Axe, 1, pp. 19-38.

TOLOLYAN Khachig (1996) Rethinking Diaspora(s): Stateless Power in the Transnational Moment, Diaspora5, pp. 3-36.

\section{NOTES}

1. Chivallon, Christine, "Beyond Gilroy's Black Atlantic: The Experience of the African Diaspora," Diaspora, 11:3 (2002): 373.

2. Gottlob, Frege, "On Sense and Reference", in Translations from the Philosophical Writings of Gottlob Frege, eds. P. Geach and M. Black, 1966, pp. 56-78. Emphasis is mine.

3. This expression is borrowed from Cohen, Robin, "The Diaspora of a Diaspora: The Caribbean Case" in Harry Woodbourne (ed.) Race and Ethnicity: Critical Concepts in Sociology, Vol.2, Solidarities and Communities, London: Routledge, 2001 [reprinted from Social science information, 31 (1) 1992, 192-203].

4. See Tallyman Khachig, "Rethinking Diaspora(s): Stateless Power in the Transnational Moment," 12-15, Diaspora 5 (1996) 3-36.

5. See Gilroy Paul, the Black Atlantic, Modernity and Double Consciousness, Harvard University Press, 1993. And for a discussion of Gilroy's view see Cohen, R. "Cultural Diaspora: The Caribbean Case," Caribbean Migration 21-35, and Global Diaspora: An Introduction, London, UCL Press and Seattle University of Washington Press 1997; Chivallon, Christine "Beyond Gilroy's Black Atlantic: the Experience of the African Diaspora," Diaspora 11:3 2002; Scott, David “"An Obscure Miracle of Connection': Discursive Tradition and Black Diaspora Criticism," Small Axe 1 (1997): 19-38.

6. Hall Stuart, "Cultural Identity and Diaspora" in Colonial Discourse and Post-Colonial Theory: A Reader, eds. Laura Chrismal and Patrick Williams, Columbia University Press, NY, 1994.

7. Diaspora comes from diaspeirein to scatter (from dia- + speirein to sow) and mean dispersion

8. For a longer discussion, see Perina, Mickaella, Citoyenneté et sujétion aux Antilles francophones, post-esclavage et aspiration démocratique, Paris, L'Harmattan, 1997.

9. Butler, Kim, “Defining Diaspora, Refining a Discourse," Diaspora 10:2 2001, 193-194.

10. Johnson-Odim Cheryl, in "Unfinished Migrations": Commentary and Response, Brent Hayes Edwards; Cheryl Johnson-Odim; Agustin Lao-Montes; Michael O. West; Tiffany Ruby Patterson, Robin D.G. Kelley (eds.) African Studies Review, Vol. 43, No.1, Special Issue on the Diaspora (Apr., 2000), p. 52.

11. See Safran, William, "Diasporas in Modern Societies: Myths of Homeland and Return," Diaspora, 1 (1991): 83-99. Safran defining characteristics are a) a dispersal to two or more locations, b) a collective mythology of the homeland, c) the alienation from the hostland, d) an idealization of a return to the homeland, e) a commitment to the maintenance and safety of the homeland and $\mathrm{f}$ ) a more generalized connection to the homeland that defines the diaspora "ethnocommunal consciousness and solidarity."

12. Césaire, Aimé, Notebook of a Return to my Native Land, translated by Clayton Eshleman and Annette Smith, Wesleyan University Press, 2001.

13. Glissant Edouard, Caribbean Discourse, Charlottesville, University Press of Virginia, 1989. Emphasis added all translations from French are my own.

14. Patterson, Tiffany Ruby, Robin D. G. Kelley, in "Unfinished Migrations": Commentary and Response, p. 65-66

15. For more on the distinction between cultural and structural assimilation see Gordon Milton, Assimilation in American Life, New-York: Oxford University Press 1964. Although his analysis focuses essentially on the US, I would argue that his distinction between cultural assimilation 
processes in which immigrants become "like" in cultural practices such as language, behavior and values and structural assimilation when immigrants are fully integrated in institutions applies to assimilation in the French context.

16. Pedraza, Silvia, “Assimilation or Diasporic Citizenship?" in Contemporary Sociology, Vol. 28, N0.4 (Jul., 1999), 381.

17. Tololyan Khacha, Diaspora, (1991):3.

18. Laó-Montes, Agustin, in "Unfinished Migrations": Commentary and Response, op. cit., 58.

19. Cohen, Robin, Global Diasporas, Cultural diasporas: the Caribbean case

20. Chow, Rey, Writing Diaspora: Tactics of Intervention in Contemporary Cultural Studies, Bloomingham Indiana University Press, 1993.

21. Recent developments in the "Indian community" in Martinique including trips to India Tamul and dance classes and the conceptualization of "Indianite" suggests a diaspora that is not in contradiction with a French political membership or a Martinican cultural membership.

22. For more on Creole language and how it shapes French overseas departments cultures see Confiant, Bernabé and Chamoiseau, Eloge de la Créolité.

23. Chivallon, Christine, La Diaspora Noire des Amériques, Paris, CNRS Editions, Coll. Espaces et Milieux, (2004) : 221.

24. Hall, Stuart, (1990): 235. Emphasis is mine.

25. Bernabé Jean, Chamoiseau Patrick, Confiant Raphaël, Eloge de la Créolité [In Praise of Creoleness], Gallimard, Paris, 1989, (1ère édition 1989), p. 14.

26. Giraud, Michel, «La Créolité : une rupture en trompe l'œil », Cahier d'Etudes Africaines, 37 (1997) : 799.

27. Glissant, Edouard, Le Chaos-monde, l'oral et l'écrit, Ecrire la parole de nuit, Paris, Essais, Gallimard, 1994. "Je partirais d'une poétique des positions actuelles de l'être-dans-le-monde, et la vision évidente en sera que l'être est chaotique dans un monde chaotique. La question qui se pose est celle-ci : ce chaos qui fissure l'être et qui divise le monde est-ce le chaos qui précède les apocalypses, les fins du monde, comme une certaine littérature le définit ? [...] Ma poétique est totalement à l'opposé. Ma poétique, c'est que rien n'est plus beau que le chaos, et qu'il n'y a rien de plus beau que le chaos-monde ».

28. Cohen, Robin, "Cultural Diaspora: the Caribbean Case" in Global Diaspora: An Introduction, London: UCL Press and Seattle: University of Washington Press, (1997):143.

29. Hintjens, Helen, Alternatives to Independence: Explorations in Post-Colonial Relations, Aldershot, Hants, England; Brookfield, Vt., USA: Darmouth Pub. Co., 1995.

30. Laguerre, Michel, Diasporic Citizenship: Haitian Americans in Transnational America, New-York: St Martin's Press, 1998.

31. Laguerre, M, op. c., p. 12.

32. Laguerre, M., op. c. p. 190.

33. Acronym for French Overseas Department (Department d'Outre-Mer)

34. Clifford, James, "Diaspora," Cultural Anthropology, Vol. 9, No 3, "Further Inflections: Toward Ethnographies of the Future (Aug. 1994)": 307.

35. Bloom, William, Personal Identity, National Identity and International Relations, Cambridge University Press, 1990, p. 52.

36. Lincoln, Bruce, Discourse and the Construction of Society: Comparative Studies of Myth, Ritual and Classification, Oxford University Press, 1989.

37. Ibid., p. 8.

38. P.W. Preston, Political/Cultural Identity, Citizens and Nations in a Global Era, SAGE publications, London, 1997, 1.

39. Césaire, Aimé, reporter of the law, presenting the conclusions of the commission including Léopold Bissol (Martinique/Guadeloupe), Gaston Monnerville (Guiana) and Raymond Vergès 
(Reunion) and discussing the propositions in favor of the departmentalization on March 1946 in front of French National Assembly.

40. See Perina, M., "Crossing Over from Slavery to Citizenship: Origins of Modern French Caribbean Democracy" in Regards sur l'Histoire de la Caraibe, des Guyanes aux Grandes Antilles, Paris, Ibis Rouge editions, 2001.

41. La défense coloniale, Martinique, March 22, 1882.

42. Nicolas, Armand, La révolution antiesclavagiste de Mai 1848 à la Martinique, Fort-de-France, Martinique, 1967, 29.

43. Balibar, E., Propositions on citizenship, in Ethics, vol. 98, N 4 (July 1988), p. 724.

\section{ABSTRACTS}

The unusual status of the French overseas departments in today «post-colonial world» provides an interesting domain of investigation from which analyzing the concept of diaspora. If diaspora refers to dispersal to several locations, to a collective mythology of a homeland and to an idealization of the return clearly the French Caribbean was initially an African diaspora. But did it stop being a diaspora once the Caribbean territory became the homeland? If diaspora can be regarded as a state of mind that imply not so much the idealization of the return but a commitment to the homeland along with a form of solidarity and a shared culture French Caribbeans relocated in Europe and elsewhere certainly qualify as part of the Caribbean diaspora. But between these two perspectives there is room for a more complex scheme: a diaspora that changed over time -occupying the Caribbean territory as its own, adopting a French political membership, generating a new diaspora- and yet remained partly the initial diaspora demonstrating that instead of stopping to be one type of diaspora to become another it can transform itself.

Le statut inhabituel des départements français d'Outre-mer dans le monde postcolonial d'aujourd'hui fourni un champ d'investigation intéressant à partir duquel analyser le concept de diaspora. Si l'idée de diaspora renvoie à la dispersion dans des lieux divers, à une mythologie collective du pays natal et à l'idéalisation du retour, la Caraïbe française remplissait initialement toutes les conditions d'une diaspora africaine. Mais s'est-elle arrêtée de l'être lorsque le territoire caribéen est devenu le pays natal ? Si la diaspora peut être considérée comme un état d'esprit qui implique non tant l'idéalisation du retour mais un engagement vis-à-vis du pays natal doublé d'une forme de solidarité et d'une culture partagée, les Français de la Caraïbe ayant immigré en Europe ou ailleurs participent certainement de la diaspora Caribéenne. Mais entre ces deux perspectives, il y a place pour un schéma plus complexe : une diaspora qui aurait changé avec le temps - s'appropriant le territoire caribéen, adoptant l'adhésion à une communauté politique française, donnant naissance à une nouvelle diaspora - mais qui serait demeurée partie intégrante de la diaspora initiale démontrant qu'au lieu de cesser d'être un type de diaspora pour en devenir un autre elle peut se transformer.

El estatuto inhabitual de los departamentos franceses del Caribe en el "mundo postcolonial" de hoy proporciona un dominio de investigación interesente a partir del cual analizar el concepto de diáspora. Si la idea de diáspora devuelve a la dispersión en distintos lugares, a una mitología colectiva de la tierra natal y a la idealización de la vuelta el Caribe francés cumplía inicialmente 
todas las condiciones de una diáspora africana. ¿Pero qué suceden cuando el territorio del Caribe se convirtió en tierra natal ? Si la diáspora se puede considerar como un estado de la mente que implica no tanto la idealización de la vuelta pero una comisión a la tierra natal junto con una forma de solidaridad y una cultura compartida, los franceses del Caribe que inmigran en Europa o en otros lugares del mundo participan ciertamente de la diáspora del Caribe. Pero entre estas dos perspectivas hay lugar para un esquema más complejo : una diáspora que habría cambiado con el tiempo apropiándose el territorio del Caribe, adoptando la adhesión a una comunidad política francesa, generando una nueva diáspora - pero que habría permanecido parte integral de la diáspora inicial demostrando un tipo de diáspora que se puede transformar.

INDEX

Geographical index: Caraïbes, DOM-TOM

Mots-clés: Caribéens, concept, diaspora

\section{AUTHOR}

\section{MICKAELLA PERINA}

Assistant Professor, Philosophy Department, University of Massachusetts Boston, 100 Morrissey Boulevard, Boston, MA 02125-3393, USA. E-mail: mickaella.perina@umb.edu 